\title{
EFFECTS OF DIETARY SELENOMETHIONINE SUPPLEMENTATION ON SEMEN QUALITY, FERTILITY AND ANTIOXIDANT STATUS OF COCKERELS
}

\author{
Sh.M. Shamiah*; Ragaa E. Abd El-Karim*; Abeir A.M. Eshera* Sara F. Fouda**; and \\ H.K. Zaghloul**** \\ *Animal Production Res. Inst., Agric. Res. Center, Ministry of Agric., Dokki, Egypt \\ **Poultry Production, Faculty of Agriculture, Mansoura University, Masoura, Egypt \\ ***High Institute for Agricultural Co-operation, Shoubra, Egypt
}

\section{SUMMARY}

$\mathrm{T}$ The aim of this study was to determine the effect of different levels of Selenomethionine (SelPlex) $(0.0,0.15,0.30$ and $0.45 \mathrm{mg} / \mathrm{kg}$ diet $)$ on semen quality, fertility and hatchability of local strain (Inshas) cockerels. Thirty six mature cockerels at 28 weeks of age were divided into four group $\{(\mathrm{G} 1(0.0), \mathrm{G} 2(0.15), \mathrm{G} 3(0.30)$ and G4 (0.45) $\} \mathrm{mg} / \mathrm{kg}$ diet $(9$ cockerels each). All birds were reared under similar management and housing-condition throughout the experimental period. Results revealed that, the final live body weight (LBW) and change of body weight of cocks in group 4 (G4) was significantly higher $(\mathrm{P}<0.05)$ than cockerels in group $\mathrm{G} 1$ and $\mathrm{G} 2$, but did not differ significantly with group G3 or between group G1 and group G2. Daily feed intake did not affected significantly by treatments. Testosterone concentration of cockerels in group 3 (G3) was significantly $(\mathrm{P}<0.05)$ higher than in other groups, while the fertility rate of cockerels in $\mathrm{G} 4$ was significantly $(\mathrm{P}<0.05)$ higher than in other groups. However no significant differences between group G3 and G4 in hatchability rate. Percentages of progressive motility and livability of cockerel spermatozoa were significantly $(\mathrm{P}<0.05)$ higher in groups $\mathrm{G} 3$ and G4 as compared as in groups G1 and G2, but the opposite trend in percentages of abnormality and acrosome damage of spermatozoa. Total antioxidant capacity (TAOC) in serum of cockerel's in group 3 (G3) was significantly higher $(\mathrm{P}<0.05)$ than in control $\mathrm{G} 1$, but no significant differences among selenium treatments, while SOD activity in serum of cockerel's was not influenced significantly by supplemented different levels of selenium. Activity Enzymes AST and ALT were significantly higher in G1 than in G3, while no significant differ among G2, G3 and G4. In conclusion, use of organic selenium supplementation $(0.3$ or $0.45 \mathrm{mg} / \mathrm{Kg})$ in diet of cockerels could be recommended to improve semen quality, fertility, hatchability and oxidative status of roosters.

Keyword: Semen, fertility, hatchability, Selenium methionine, cockerels.

\section{INTRODUCTION}

Chicken spermatozoa are characterized by comparatively high levels of 20: 4 n-6 and 22: 4 n-6 fatty acids within their phospholipids (Blesbois et al., 1997). As a result of this high proportion of polyunsaturated fatty acids (PUFA) chicken semen is susceptible to lipid peroxidation, which could lead to sperm damage (Syrai et al., 1998)

Imbalance between reactive oxygen species and total antioxidant capacity can cause male infertility (Kazama and Hino 2012; Drevet, 2012). Selenium as a component of glutathione peroxidase protects spermatozoa, spermatogonia and sperm cells themselves against the free oxygen radicals (Noblanc et al., 2011 and Abdalla et al., 2016)

Selenium (Se) is an essential trace element that is necessary for the maintenance of various physiological processes (Zhang et al., 2006). In a cell culture system, selenium in the form of sodium selenite (SS) protects the cells from oxidative damage by reducing the production of free radicals and inhibits lipid peroxidation (Tatemoto et al., 2004).

The health of the reproductive system of livestock has a vital role to achieve high reproductive performance. Reproduction is one of the most important production parameters in attaining profitability in a commercial farm operation. Selenium is essential for the maintenance of male fertility in human 


\section{Shamiah et al.}

(Brown and Arthur, 2001) and rabbits (Kamel, 2012) also, is required for testosterone biosynthesis, and for formation and normal development of spermatozoa (Behne et al., 1996). Both the testis and epididymis require exogenously supplied selenium in order to synthesize a variety of selenoproteins (Shalini and Bansal, 2007).

Selenium deficiency in the diet leads to the decline of ejaculate quality, which causes deteriorated fertilizing ability (Camejo et al., 2011). Two selenium forms, organic and inorganic, are available, whereas it is assumed that organic form has more bioavailability and consequently, reduced toxicity compared to inorganic one (Brennan et al., 2011).

The aim of the current work was to study the effect of different levels of organic selenium $(0.0$, $0.15,0.30$ and $0.45 \mathrm{mg} / \mathrm{kg}$ diet on semen quality, fertility and hatchability of local strain (Inshas) cockerels.

\section{MATERIAL AND METHODS}

This study was carried out at the El-Sanafawy Farm, Sakha, Kafr El-Sheikh, Egypt.

\section{Birds and experimental design:}

A total number of 36 mature cocks of Inshas strain as a local strain at 28 weeks till 40 weeks of age were used in the present study. All birds were reared under similar management and housed individually in single cages in an open system house. Feed and water were offered ad libitum throughout the experimental period. The cockerels were randomly distributed into 4 experimental treatments, control and 3 supplemented treatments ( 9 cocks each).

\section{Experimental diets:}

The basal experimental diet was formulated to meet the nutrient requirements of local strain of chicken at laying period as recommended by Feed composition Tables for Animal \& poultry feedstuffs used in Egypt (2001). Composition and calculated analysis of basal diet are shown in (Table 1). The $1^{\text {st }}$ treatment (control) was given the basal laying diet without Selenomethionine (Sel-Plex). While, the $2^{\text {nd }}$, $3^{\text {rd }}$ and $4^{\text {th }}$ treatment was fed the basal diet supplemental with $0.15,0.30$ and $0.45 \mathrm{mg}$ Sel-Plex/ $\mathrm{kg}$ diet, respectively.

\section{Collected data:}

\section{Measurements:}

Cocks were individually weighed at the beginning and end of the experimental period to the nearest 0.1 gram. Changes in live body weight were calculated as the differences between the two weights. Daily feed intake was recorded for each treatment. All data were calculated for each replicated and treatment throughout the experimental period.

\section{Blood samples:}

Blood samples were collected from brachial vein from each group after 10 days of treatment beginning and at the end of experiment. Blood serum was separated by centrifugation of blood at 3000 $\mathrm{rpm}$ for $15 \mathrm{~min}$ and stored at $-20^{\circ} \mathrm{C}$ until analysis.

\section{Assays:}

Alkaline phosphatase (ALP) was determined in serum by the method of Belfieid and Goldberg (1971), Total antioxidant capacity (TAOC) (Said et al., 2003), Superoxid dismutase (SOD) (Nishikimi et al., 1972), activity of aspartate (AST) and alanin (ALT) transaminases (Reitman and Frankel, 1957) and testosterone concentration assay by ELISA (Sauer et al., 1982).

\section{Semen quality:}

Semen samples were collected from each cockerel twice weekly by the abdominal massage method (Lake and Stewart, 1978). Semen samples were examined for the following characteristics:

Ejaculate volume was determined to the nearest $0.01 \mathrm{ml}$. using $1.0 \mathrm{ml}$. tuberculin syringe. Sperm concentration was determined by using Thomaes-Zeis haemocytometer. While, total sperm output was calculated as (ejaculate volume $\mathrm{x}$ sperm concentration). 
The progressive motility percentage was assessed according to (Tabatabaei et al., 2009). Sperm livability percentage was determined using eosin/nigrosin stain according to (Lukaszewicz et al., 2008), Sperm abnormalities percentage was determined during the examination of sperm livability at a high power magnification $(400 \mathrm{x})$.

The percentage of acrosomal abnormalities, staining procedure for fixed samples have been developed to distinguish which spermatozoa have retained or lost the acrosome (Al- Daraji, 2001).

\section{Morphometric of testis measurement:}

At the end of the experiment, three cocks of each treatment were slaughtered, immediately testicular characteristics were recorded, in terms of weight, circumference, length and diameter of each testis. Testicular measurements were taken using a measuring tape rule.

\section{Fertility trail:}

At the $40^{\text {th }}$ week of age, cocks divided each replicates by 1 cockerel and 7 hens each from the same strain. Each replicate was housed in each group cages $(120 \times 100 \times 0.75 \mathrm{~cm})$ with the same treatments. Eggs were daily collected from each treatment and incubated to determine fertility and hatchability percentage as fellow:-

Fertility percentage $=($ fertile eggs/total eggs $) \times 100$.

Hatchability percentage $=($ hatched chick/fertile eggs $) \times 100$.

\section{Statistical analyses:}

Data obtained were statistically analyzed as a one way design for change in weight, testis measurement, semen characteristics and fertility and two way design for enzymatic activity using analysis of variance (ANOVA) (SAS, 2001). A significant difference was used at 0.05 probability level and differences among treatments were tested using the Duncan's procedure (Duncan, 1955).

\section{RESULTS AND DISCUSSION}

\section{Growth performance:}

Results in Table (2) reveal that final live body weight (LBW) and change in BW of cockerels treated with different doses of Se in groups $(\mathrm{G} 4, \mathrm{G} 3$ and G2) was significant higher $(\mathrm{P}<0.05)$ as compared to control group G1. Statistical analysis for data in Table 2 reveal that final live body weight $(\mathrm{LBW})$ and change in BW of cockerels in group $4(\mathrm{G} 4)$ was significantly the highest $(\mathrm{P}<0.05)$ than cockerels in groups G3, G2 and G1. These results is agree with Choct et al., (2004) who found that live body weight of broiler chicks was significantly improved by supplementing diet with selenium. And revealed this enhancement due to that selenium is an essential for growth and performance.

Cocks fed dietary different levels of selenium did not show any significant differences among all groups in daily feed intake (Table 2). These results are harmony with El-Slamony et al., (2015) who illustrated that supplementation of diet with 0.2 or $0.3 \mathrm{mg} / \mathrm{kg}$ diet as Sel-Plex had no significant effect on feed intake of laying hens. Also, Abdalla et al., (2015) reach to the same conclusion in cocks.

\section{Morphometry of the testis:}

Results presented in Table (2) reveal that cockerel testicular weight (absolute) was insignificantly higher $(\mathrm{P}<0.05)$ in groups $(\mathrm{G} 4, \mathrm{G} 3$ and G2) as compared to control group $\mathrm{G} 1$, also, testicular (length and circumferences) were not affected significantly $(\mathrm{P}<0.05)$ by level of Se supplemented to diet, being higher in G3, than other groups, while testicular diameters was similarity in (G3 and G1) and higher than G4 and G2. These findings reflected the importance of Se supplementation to diet which had a numeric effect on measures of testes (Table 2).

\section{Semen quality, fertility and hatchability:}

Results presented in Table (3) show that percentages of progressive motility and livability of cockerel spermatozoa were significantly $(\mathrm{P}<0.05)$ higher in groups $\mathrm{G} 3$ and $\mathrm{G} 4$ as compared to both groups G1 and G2, but the opposite trend in percentages of abnormality and acrosome damage of spermatozoa. The ejaculate volume and total sperm output were not significant affected by levels of Se supplemented. The present study is agreement with Jafari et al., (2013) who found that the organic selenium supplementation had significant effects on sperm motility and viability in liquid condition. 


\section{Shamiah et al.}

The use of organic selenium at the level of $0.3 \mathrm{mg} / \mathrm{Kg}$ significantly improved sperm motility and viability at storage times of $4,8,12$ and $24 \mathrm{~h}$ as well as had lower abnormal sperm percentage in comparison with the control group.

Alm El-Dein and Soliman (2015) showed that the highest values of ejaculate volume, sperm concentration, live sperm percentage, sperm motility, total sperm per ejaculate and total live sperm per ejaculate at 30 and 36 wks of age were recorded by Inshas cocks groups fed 0.6 and $0.8 \mathrm{mg} \mathrm{Se} / \mathrm{kg}$ diet compared to cocks of control. On the opposite, abnormal sperm percentage and total abnormal sperm per ejaculate was higher in cocks of control group compared to selenomethionine groups. Also, Madkour et al., (2015) indicated that the fertility and hatchability percentages were significantly increased by increasing dietary Se level in Japanase Quail. Jerysz and Lukaszewicz (2013) reported that the supplementation of selenium to diet of male significantly increased ejaculate volumes, sperm concentrations, and percentages of viable sperm while decreased percentages of immature sperm (spermatids). Also, Lipids peroxidation, expressed in terms of the malondialdehyde concentration, was lower in semen of the supplemented group as compared to the control.

Selenium is a trace element and frequently added to animal diet as a supplement for the maintenance of reproductive functions, and a deficiency in dietary selenium causes a decrease in sperm concentration, sperm motility, and sperm capacity in humans, lab animals, and farm animals, including poultry species (Hansen and Deguchi 1996). Selenium is a component of selenoproteins, such as glutathione peroxidase, which protect sperms against oxidative damage (Ahsan et al., 2014).

A deficiency in dietary selenium can result in decreased numbers of normal spermatozoa per ejaculate, decreased motility and decreased fertilizing capacity. These phenomena have been demonstrated in rodents, humans and poultry such as chickens, turkeys and ducks (Surai, 2000 and Surai et al., 2001).

Selenium deficiency has been linked to reproductive problems in rats, mice, chickens, pigs, sheep, and cattle (Combs and Combs, 1986) and supplementation with selenium has been reported to improve reproductive performance in sheep and mice (Tang et al., 1991 and Van Ryssen et al., 1992). Selenium is required for normal testicular development and spermatogenesis in rats (Behne et al., 1996), mice, and pigs (Combs and Combs, 1986).

Effect of varying levels of organic selenium on cocks serum testosterone, fertility \% and hatchability $\%$ are presented in Table (3). Group G3 (fed $0.3 \mathrm{mg}$ Sel-Plex/kg diet) recorded significantly the highest value for testosterone concentration comparing to other groups. In this respect, Abdalla et $a l$. , (2015) found that concentration of plasma testosterone hormone increased gradually as the level of Se increased in the diet $(0.2$ and $0.3 \mathrm{mg}$ Sel-Plex $/ \mathrm{kg}$ feed $)$ of cocks but there was no significant difference among treatments. On the other hand, group G4 achieved the highest percentage of fertility and hatchability comparing to either control group or others fed dietary supplemented Se.

Vitamin E-Selenium supplementation had significant $(\mathrm{P}<0.05)$ effect on fertility and hatchability of quails. Highest fertility (88\%) and hatchability $(81 \%)$ were recorded in mating subgroup supplemented with vitamin E-Selenium. Mating group is recommended for better fertility and hatchability and economic perspective (Umar et al., 2013 and Alm El-Dein and Soliman 2015).

\section{Enzymatic activity:}

Table (4) show that total antioxidant capacity (TAOC) in cocks serum was significantly influenced by supplementing different levels of selenium, which G3 $(0.30 \mathrm{mg})$ recorded significantly higher value $(\mathrm{P}<0.05)$ than in control G1, but no significant differences appeared among supplemental groups.

Values of serum TAOC of weaning pigs fed dietary $0.3 \mathrm{mg} \mathrm{Se} / \mathrm{kg}$ diet as selenomethionine was significantly enhanced comparing to others fed the same level as sodium selenite (Cao, et al., 2014)

It was widely accepted that proper Se intake could enhance the antioxidant status of the body. TAOC indicates the oxidation resistance capacity of the whole body. Wang et al. (2011) pointed out that $0.15 \mathrm{mg} / \mathrm{kg}$ of selenomethionine supplementation in broiler diet was more effective than sodium selenite to increase TAOC and decrease MDA concentration in serum and organs. 
Table (4) show the SOD activity in serum of cockerel's was not influenced significantly by supplementing different levels of selenium.

Analysis of variance showed that the TAOC, $\mathrm{mM} / \mathrm{L}$ and SOD MM/L activity was significantly higher at the end of experimental than initial $(1.08$ vs. $0.997 \mathrm{mM} / \mathrm{L})$ and $(175.79 v s .164 .05 \mathrm{mM} / \mathrm{L})$, respectively, while, the interaction between treatment and time of sample were not affected significantly (Table 4).

Selenium (Se) is an essential trace element that is necessary for the maintenance of various physiological processes (Zhang et al., 2006). In a cell culture system, selenium in the form of sodium selenite (SS) protects the cells from oxidative damage by reducing the production of free radical and inhibits lipid peroxidation (Tatemoto et al., 2004).

Activity enzymes, aspartate (AST) and alanin (ALT) transaminases were significantly $(\mathrm{P}<0.01)$ higher in G1 than other groups, but in G2 were significantly $(\mathrm{P}<0.01)$ higher than in G3 and G4, while no significant differ between G2 and G3 or between G3 and G4 Table 4. Also, the enzymatic activity, aspartate (AST) and alanin (ALT) transaminases were significantly $(\mathrm{P}<0.01)$ higher in the final of experimental period than in initial. However the interaction between treatment and time of sample were not affected significantly (Table 4).

Several studies reported that the concentrations of ALT and AST in plasma were decreased by increasing level of Se in diets, Iqbal et al., (2013), El-Slamony et al., (2015) and Abdalla et al., (2015)

Table (4) shows the alkaline phosphatase activity in serum of cockerel's was not influenced by supplementing different levels of selenium, but the general tendency was higher in group G3 (0.30 mg $\mathrm{Se} / \mathrm{kg}$ diet $)$ and lower in group $\mathrm{G} 2(0.15 \mathrm{mg} \mathrm{Se} / \mathrm{kg}$ diet $)$ than in other groups.

Oxygen species are very active on the cellular level resulting in various degrees of damage to the sperm cells. Sperm cells are very susceptible to lipid peroxidation by free radicals such as hydrogen peroxide, superoxide anion, and hydroxyl radical which could later lead to the structural damage of sperm membranes during the aerobic storage of sperm (Surai et al., 1998).

Dietary Se could prevent lipid peroxidation of biological membranes. The results of increasing glutathione peroxidase activity in serum by organic Se in this experiment were in agreement with previous reports (Jiang et al., 2009). These findings suggested that Se-enriched yeast improved antioxidative status of broilers by elevating activities of antioxidant enzymes, and also implicated that Se-enriched yeast supplementation may have a beneficial effect on oxidative stability and extended shelf life of fresh meat than sodium selenite.

\section{CONCLUSION}

In conclusion, use of organic selenium supplementation $(0.3$ or $0.45 \mathrm{mg} / \mathrm{Kg})$ in diet of cockerels could be recommended to improve semen quality, fertility, hatchability and oxidative status of roosters.

\section{REFERENCES}

Abdalla, E.A., A.E. El-Slamony, M.M. Sabry, A.A. Faddle and Hanan S. Mohamed, (2015). Effect of dietary selenium and zinc on some sex hormones and performance of Golden Montazah during summer season. 2-effect on males. Egypt. Poult. Sci. (35) (111): 799-815.

Ahsan, U., Kamran, Z., Raza, I., Ahmad, S., Babar, W., Riaz, M.H., and Iqbal, Z., (2014). Role of selenium in male reproduction-A review. Anim. Reprod. Sci.146, 55-62.

Al-Daraji, H.J., (2001). Effects of holding temperature and time on acrosomal abnormalities of fowl sperms. Indian J Anim. Sci., 71(1): 32-34.

Alm El- Dein, A.K. and M.M. Soliman, (2015). Effect of dietary selenium methionine supplementation on some productive, reproductive and immunological traits of Inshas chickens strain. Egypt. Poult. Sci. Vol. (35) (IV): (1009-1029). 


\section{Shamiah et al.}

Behne, D., Weiler H. and Kyriakopoulos A., (1996). Effects of selenium deficiency on testicular morphology and function in rats. J. Repro Fert 106: 291-297.

Belfield A, Goldberg D. (1971) Colorimetric determination of alkaline phosphatase activity. Enzyme; 12: $561-566$.

Blesbois, E., M. Lessire, I. Grsseau, J. M. Hallouis and D. Hermier. 1997. Effect of dietary fat on the fatty acid composition and fertilizing ability of fowl semen. Biol. Reprod. 56: 1216 - 1220.

Brennan, K.M. Crowdus, C.A. Cantor, A.H. Pescatore, A.J. Barger, J.L. Horgan, K. Xiao, R. Power R.F. and Dawson, K.A., (2011). Effects of organic and inorganic dietary selenium supplementation on gene expression profiles in oviduct tissue from broiler-breeder hens Anim. Reprod. Sci., 125180.

Brown K.M. \& Arthur J.R., (2001). Selenium, selenoproteins and human health: a review. Publ Health Nutr 4: 593-599.

Camejo, M.I. Abdala, L. Vivas-Acevedo, G. Lozano-Hernandez, R. Angeli-Greaves M. and Greaves, E.D. (2011). Selenium, copper and zinc in seminal plasma of men with varicocele, relationship with seminal parameters. Biol. Trace Elem. Res., 1243-1247.

Cao, J., F. Guo, L. Zhang, B. Dong and L. Gong (2014). Effects of dietary Selenomethionine supplementation on growth performance, antioxidant status, plasma selenium concentration, and immune function in weaning pigs. J. of Animal Sci. and Bio. 5:42-46.

Choct, M., A.J. Naylor and N. Reinke (2004). Selenium supplementation affects broiler growth performance, met yield and feather coverage. Br. Poult. Sci., (45): 677-684.

Combs G.F. J.R. and Combs S.B. (1986). The Role of Selenium in Nutrition. San Diego: Academic Press.

Drevet, J.R. (2012). Protection of Epididymal Spermatozoa from Oxidative Stress, Springer, New York.

Duncan, B.D. (1955). Multiple range and multiple F test. Biometrics 11: 1-42.

El-Slamony, A.E., E.A. Abdalla, A.A. Faddle, Hanan S. Mohamedand, M.M. Sabry (2015). Effect of supplemnting selenium and zinc in diet on some sex hormones, productive, reproductive and physiological parameters of laying Golden Montazah chicken during summer season. 1- The effect on females. Egypt. Poult. Sci. (35) (111): 647-672.

Feed Composition Tables For Animal and Poultry Feedstuffs Used In Egypt 2001. Technical bulletin No.1, central lab for Feed and food; Ministry of Agriculture, Egypt.

Hansen, J.C. and Deguchi, Y. (1996). Selenium and fertility in animals and man-A review. Acta Vet. Scand. 37, 19-30.

Iqbal R, T. Aziz, I. Sarfaraz, R. Shabir, M. S. Ansari, M.F. Malik, R. Saleem, A. Zahra and S. Mehwish (2013). Effect of vitamin $\mathrm{E}$ and selenium on immunity, egg production and lever function in laying hens (HY-LINE W-98). Middle-East J. Sci. Res., (9): 1165-1170.

Jafari Y.A., B. Parizadian and M. Zamani (2013). The Impact of Organic Selenium Supplementation on Rooster Semen Quality in Liquid Condition. Poultry Science Journal, 1 (1): 21-28.

Jerysz A. and Lukaszewicz E. (2013). Effect of dietary selenium and vitamin E on ganders' response to semen collection and ejaculate characteristics. Biol Trace Elem Res. 153: 196.

Jiang Z.Y., Lin Y.C., Zhou G.L., Luo L.H., Jiang S.Q., Chen F., (2009). Effects of dietary selenomethionine supplementation on growth performance, meat quality and antioxidant property in yellow broilers. J. Agric. Food. Chem. 57: 9769-9772.

Kalamah, M.A., El-Nadi, M.M., Goher, L.M. and Soliman, M.M., (2000). Some factors affecting fertility and hatchability using artificial insemination in Norfa chickens. 3rd All Africa Conf. on Anim. Agric. And 11th Conf. of the Egyptian Society of Anim. Prod., Alex. Egypt, Nov., 597-605.

Kamel, I.K., (2012). The effect of dietary organic selenium and folic acid supplementation on productive and reproductive performance of male rabbits under heat stress conditions. Egypt. Poult. Sci. (32): 43-62.

Kazama M. and Hino, A., (2012). Sea urchin spermatozoa generate at least two reactive oxygen species; the type of reactive oxygen species changes under different conditions. Mol. Reprod. Dev., 79: 283.

Lake, P.E. and Stewart, J.M., (1978). Artificial insemination in poultry. Bulletin 213, Ministy of Agriculture Fisheries and food, London. 
Lukaszewicz, E., Jersey, A., Partyka, A. and Siudzinska, A., (2008). Efficacy of evaluation of rooster sperm morphology using different staining methods. Res. Vet. Sci., 85: 583-588

Madkour, M., H.M. Ali, S.A. Yassein, S.A. Abdel-Fattah, Hewida M. El-Allawy and El-Wardany, (2015). Effect of Dietary Organic Selenium Supplement on Growth and Reproductive Performance of Japanase Quail Breeders and Their Progeny and its Relation to Antioxidation and Thyroid Activity. International Journal of Poultry Science, 14: 317-324.

Nishikimi, M., Rao, N.A., and Yagi, K. (1972) The occurrence of superoxide anion in the reaction of reduced phenazine methosulphate and molecular oxygen. Biochemical Biophysical Research Communications,46 (2), 849- 854.

Noblanc, A., Kocer, A. Chabory, E. Vernet, P. Saez, F. Cadet, R. Conrad M. and Drevet, J. R., (2011). Glutathione peroxidases at work on epididymal spermatozoa: an example of the dual effect of reactive oxygen species on mammalian male fertilizing ability. J. Androl., 32: 641.

Reitman, S. and Frankel, S., (1957). A colorimetric method for the determination of serum glutamate oxaloacetate and pyruvate transaminase. Am. J. Clin. Pathol., 28: 56-63.

Said T.M., Kattal N., Sharma R.K., Sikka S.C., Thomas A.J. Jr., Mascha E., and Agarwal A. (2003) Enhanced chemiluminescence assay vs colorimetric assay for measurement of the total antioxidant capacity of human seminal plasma. J Androl., 24: 676-680

SAS, Institute (2001). SAS User's Guide: Statistics version 6.12 ed. SAS Institute, Inc., Cary, NC., USA.

Sauer, M.J., Cookson, A.D., McDonald, B.J. and Foulkes, J.A., (1982). The use of enzyme immunoassay for the measurement of hormones with particular reference to the determination of progesterone in unextracted whole milk. In: Wardley, RC and Crowther, JR (Eds.), The ELISA. (1st. Edn.), The Netherlands, Martinus Nijhoff Publishers. PP: 271-296.

Shalini S. and Bansal MP (2007). Alterations in selenium status influences reproductive potential of male mice by modulation of transcription factor NFkB. Biometals 20: 49-59.

Surai, P. F., E. Blesbois, I. Grasseau, T. Chalah, J. P. Brillard, G. J. Wishart, S. Cerolini, and N. H. C. Sparks. (1998). Fatty acid composition, glutathione peroxidase and superoxide dismutase activity and total antioxidant activity of avian semen. Comp. Biochem. Physiol. B Biochem. Mol. Biol. 120:527-533.

Surai, P.F., (2000). Organic selenium: benefits to animals and humans, a biochemist's view. Pages 205 260. In: Biotechnology in the Feed Industry, Proceedings of Alltech's 16th Annual Symposium. T.P. Lyons and K. A. Jacques, Eds. Nottingham University Press, Thrumpton, Nottingham, UK.

Surai, P.F., N. Fujihara, B.K. Speake, J.P. Brillard, G.J. Wishart and N.H.C. Sparks (2001). Polyunsaturated fatty acids, lipid peroxidation and antioxidant protection in avian semen. AsianAust. J. Anim. Sci., 14: 1024-1050.

Syrai, P.E., S. Cerrolini, G.J. Wishart, B.K. Speake, R.C. Noble and N.H.C. Sparks (1998). Lipid and antioxidant composition of chicken semen and its susceptibility to peroxidation. Poultry Av. Biol. Rev. 9(1): $11-23$.

Tabatabaei S., Batavani R.A., and Talebi A.R., (2009). Comparison of semen quality in indigenous and Ross broiler breeder roosters. J. Anim. Vet. Adv. 8(1):90-93

Tang C.C., Chen H.N. and Rui H.F., (1991). The effects of selenium on gestation, fertility and offspring in mice. Biol Trace Elem Res. 30:227-231.

Tatemoto H., Muto N., Sunagawa I., Shinjo A. and Nakada T., (2004). Protection of porcine oocytes against cell damage caused by oxidative stress during in vitro maturation: role of superoxide dismutase activity in porcine follicular fluid. Biol. Reprod. 71:1150-1157.

Umar A., S. Khan, Rafiullah, N. Chand, Z. A. Shah, A. Akhtar and A.J. Tanweer (2013). Effect of male to female ratio and vitamin-e selenium on fertility, hatchability and hatched chick weight of quail breeders. Sarhad J. Agric. Vol.29, No.3, 2013

Van Ryssen J.B.J., Bradfield G.D., Van Malsen S., D. and Villers J.F., (1992). Response to selenium supplementation of sheep grazing cultivated pastures in the natal midlands. J S Afr Vet Assoc. 63:148-155.

Wang Y.X., Zhan X.A., Yuan D., Zhang X.W., Wu R.J., (2011). Effects of selenomethionine and sodium selenite supplementation on meat quality, selenium distribution and antioxidant status in broilers. Czech J Anim Sci., 56:305-311. 


\title{
Shamiah et al.
}

Zhang J., Robinson D., and Salmon P. (2006). A novel function for selenium in biological system: selenite as a highly effective iron carrier for Chinese hamster ovary cell growth and monoclonal antibody production. Biotechnol Bioeng. 95:1188-1197.

\section{تأثير إضافة السيلينيوم في العلف على وزن الجسم والخصوبة و جودة السائل المنوى والحاله التأكسديه فى

\author{
*شريف مغاورى شامياه،رجاء السيد عبد الكريم ،*عبير أحمد عشره ،**شاره فؤاد ،***حمى زغلول \\ * معه بحوث الإتتاج الحيوانسي- مركز البحوث الزراعية ، **كلية الزراعه- جامعة المنصوره ، ****المعه الزراعى بشبرا.
}

الهدف من هذه الدراسة هو تحديد تأثير مستويات مختلفة من سلينوميثيونين (Sel-Plex) على صفات جودة السائل المنوي،

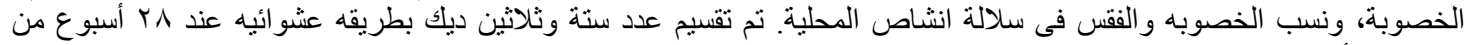

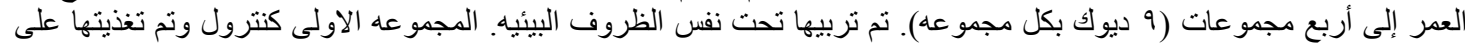

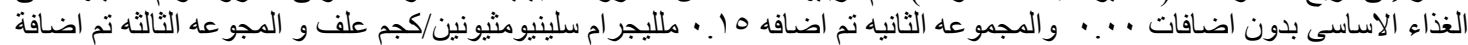
• ب. • ملليجر ام سلينيو مثيونين/كجم علف و المجمو عه الر ابعة تم اضافة

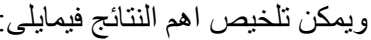

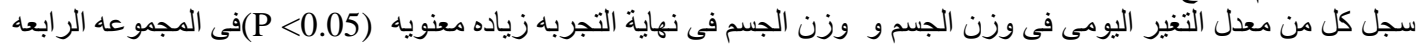

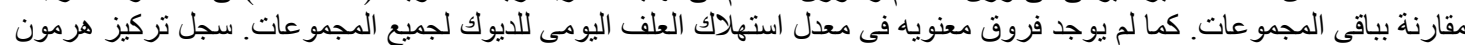

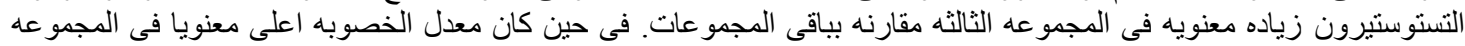

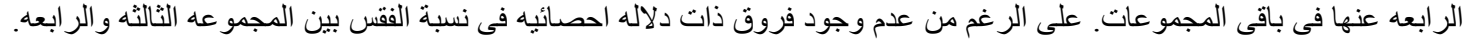

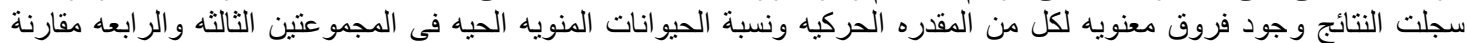

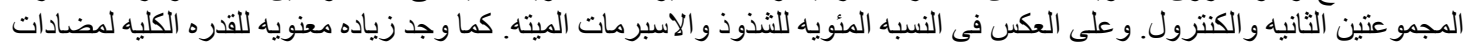

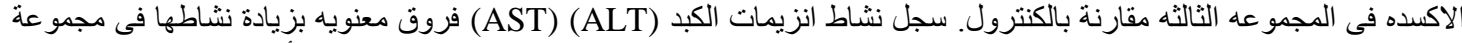

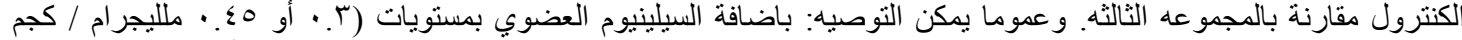

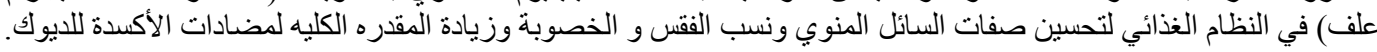


Table (1): Composition and calculated analysis of experimental basal diets

\begin{tabular}{lclc}
\hline Ingredients & $\begin{array}{c}\text { Percentage } \\
(\%)\end{array}$ & \multicolumn{1}{c}{ Calculated analysis** } & $\begin{array}{c}\text { Percentage } \\
(\%)\end{array}$ \\
\hline Yellow corn & 66.00 & Metabolizable energy (Kcal/Kg) & 2747 \\
Soybean Meal (44\%) & 23.00 & Crude protein \% & 15.67 \\
Wheat Bran & 2.50 & Crude fiber \% & 3.46 \\
Di-Calcium Phosphate & 1.50 & Crude fat \% & 2.96 \\
Limestone & 6.20 & Calcium \% & 3.34 \\
Salt (Na CL) & 0.40 & Available Phosphorus \% & 0.42 \\
DL-Methionine & 0.10 & Lysine \% & 0.89 \\
Vit. \& Min. Mixture* & 0.30 & Methionine \% & 0.39 \\
Total & 100.00 & Methionine +cysteine \% & 0.66 \\
\hline
\end{tabular}

*Each Kg content: Vit. A, 10000IU; Vit. D3, 2000IU, Vit. K3, Img; Vit.E,10mg; Vit. B1, Img, Vit. B2, 5mg, Vit. B6, 1.5mg, Vit. B12, 10mg, Niacin, 30mg, Pantothenic acid 10mg, Folic acid 1mg, Biotin, 50mcg, Choline, 260mg, Copper 4mg, Iron, 30mg, Manganese 60mg; Zinc $50 \mathrm{mg}$ and Iodin 1.3mg, Selenium, 0.1mg, Cobalt, 0.1mg. **According to feed composition Tables for animal \& poultry feedstuffs used in Egypt (2001).

Table (2): Live body weight and testes measurements of cockerel fed with different levels of selenium.

\begin{tabular}{lcccc}
\hline \multirow{2}{*}{ Parameters } & \multicolumn{3}{c}{ Treatments $(\mathrm{mg} \mathrm{Se} / \mathrm{kg} \mathrm{diet})$} \\
& G1 Control & G2 $(0.15 \mathrm{mg})$ & $\mathrm{G} 3(0.30 \mathrm{mg})$ & $\mathrm{G} 4(0.45 \mathrm{mg})$ \\
\hline Live body weight (LBW) & & & & \\
Initial LBW (g) & $1828.3 \pm 0.83$ & $1826.7 \pm 9.28$ & $1823.3 \pm 10.9$ & $1825.0 \pm 11.3$ \\
Final LBW (g) & $1961.7 \pm 9.61^{\mathrm{d}}$ & $2128.3 \pm 7.41^{\mathrm{c}}$ & $2210.0 \pm 5.0^{\mathrm{b}}$ & $2273.3 \pm 3.73^{\mathrm{a}}$ \\
Change BW (g/day) & $1.19 \pm 0.08^{\mathrm{d}}$ & $2.69 \pm 0.02^{\mathrm{c}}$ & $3.45 \pm 0.08^{\mathrm{b}}$ & $4.00 \pm 0.07^{\mathrm{a}}$ \\
Daily feed intake (g/cockerel/day) & $121.9 \pm 0.12$ & $121.4 \pm 0.20$ & $121.2 \pm 0.42$ & $121.2 \pm 0.15$ \\
Testes measurements & & & & \\
Weight (g) & $25.33 \pm 1.20$ & $26.97 \pm 2.94$ & $27.43 \pm 3.53$ & $28.53 \pm 1.87$ \\
Length (cm) & $5.2 \pm 0.55$ & $4.8 \pm 0.27$ & $5.4 \pm 0.40$ & $4.1 \pm 0.32$ \\
Diameter (cm) & $21.5 \pm 1.15$ & $19.5 \pm 2.57$ & $21.5 \pm 0.76$ & $19.0 \pm 0.76$ \\
Circumferences (cm) & $6.7 \pm 0.32$ & $6.2 \pm 0.30$ & $7.1 \pm 0.05$ & $6.3 \pm 0.25$ \\
\hline
\end{tabular}

$a, b$ and $c:$ Means denoted within the same row with different superscripts are significantly different at $P<0.01$

Table (3): Semen characteristics, serum testosterone, fertility $\%$ and hatchability $\%$ as affected by level of selenium

\begin{tabular}{lcccc}
\hline \multirow{2}{*}{ Parameters } & \multicolumn{3}{c}{ Treatments mg Se/kg diet } \\
\cline { 2 - 5 } & G1 Control & G2 $(0.15 \mathrm{mg})$ & G3 $(0.30 \mathrm{mg})$ & $\mathrm{G} 4(0.45 \mathrm{mg})$ \\
\hline Ejaculate volume (ml) & $0.553 \pm 0.077$ & $0.589 \pm 0.069$ & $0.644 \pm 0.095$ & $0.553 \pm 0.067$ \\
Sperm concentration (x10 $/ \mathrm{ml})$ & $1.789 \pm 0.064^{\mathrm{b}}$ & $1.894 \pm 0.11^{\mathrm{ab}}$ & $1.925 \pm 0.082^{\mathrm{ab}}$ & $2.073 \pm 0.063^{\mathrm{a}}$ \\
Total sperm output (x10 $/$ ejac.) & $0.962 \pm 0.102$ & $0.972 \pm 0.098$ & $1.175 \pm 0.161$ & $1.189 \pm 0.13$ \\
Mass motility (\%) & $63.75 \pm 1.5^{\mathrm{b}}$ & $65.83 \pm 1.93^{\mathrm{b}}$ & $80.00 \pm 1.23^{\mathrm{a}}$ & $84.17 \pm 1.0^{\mathrm{a}}$ \\
Live sperm (\%) & $67.25 \pm 1.51^{\mathrm{c}}$ & $68.92 \pm 2.25^{\mathrm{c}}$ & $81.75 \pm 1.21^{\mathrm{b}}$ & $87.08 \pm 1.11^{\mathrm{a}}$ \\
Sperm abnormality (\%) & $11.58 \pm 0.57^{\mathrm{a}}$ & $8.42 \pm 0.56^{\mathrm{b}}$ & $6.42 \pm 0.68^{\mathrm{c}}$ & $3.92 \pm 0.53^{\mathrm{d}}$ \\
Damaged acrosome $(\%)$ & $4.58 \pm 0.31^{\mathrm{a}}$ & $4.17 \pm 0.49^{\mathrm{ab}}$ & $3.25 \pm 0.35^{\mathrm{bc}}$ & $2.67 \pm 0.26^{\mathrm{c}}$ \\
Testosterone concentration & $0.49 \pm 0.02^{\mathrm{d}}$ & $1.87 \pm 0.04^{\mathrm{c}}$ & $2.45 \pm 0.03^{\mathrm{a}}$ & $2.02 \pm 0.05^{\mathrm{b}}$ \\
Fertility (\%) & $82.5 \pm 0.58^{\mathrm{d}}$ & $89.4 \pm 0.70^{\mathrm{c}}$ & $92.0 \pm 0.30^{\mathrm{b}}$ & $94.3 \pm 0.46^{\mathrm{a}}$ \\
Hatchability $(\%)$ from fertile eggs & $75.6 \pm 1.13^{\mathrm{c}}$ & $86.4 \pm 0.78^{\mathrm{b}}$ & $89.3 \pm 0.58^{\mathrm{a}}$ & $92.1 \pm 0.70^{\mathrm{a}}$ \\
\hline
\end{tabular}

a, b, c and d: Means denoted within the same row with different superscripts are significantly different at $\mathrm{P}<0.01$ 
Shamiah et al.

Table (4): Enzymatic activity in serum of cockerel fed with different levels of selenium.

\begin{tabular}{lccccc}
\hline \multirow{2}{*}{ Item } & $\begin{array}{c}\text { ALP } \\
\text { U/mL }\end{array}$ & $\begin{array}{c}\text { AST } \\
\text { U/L }\end{array}$ & $\begin{array}{c}\text { ALT } \\
\text { U/L }\end{array}$ & $\begin{array}{c}\text { TAOC } \\
\text { mM/L }\end{array}$ & $\begin{array}{c}\text { SOD } \\
\text { mM/L }\end{array}$ \\
\hline Treatment (mg Se/kg diet): & & & & \\
(G1) Control & $89.99 \pm 7.88$ & $25.18 \pm 1.47^{\mathrm{a}}$ & $49.93 \pm 2.10^{\mathrm{a}}$ & $0.99 \pm 0.02^{\mathrm{b}}$ & $166.02 \pm 8.39$ \\
(G2) $0.15 \mathrm{mg}$ & $83.27 \pm 8.65$ & $20.28 \pm 1.05^{\mathrm{b}}$ & $44.38 \pm 1.69^{\mathrm{b}}$ & $1.07 \pm 0.02^{\mathrm{b}}$ & $173.51 \pm 4.77$ \\
(G3) $0.30 \mathrm{mg}$ & $97.06 \pm 5.96$ & $17.53 \pm 1.18^{\mathrm{bc}}$ & $39.19 \pm 1.89^{\mathrm{bc}}$ & $1.08 \pm 0.06^{\mathrm{a}}$ & $165.45 \pm 3.64$ \\
(G4) 0.45 mg & $95.52 \pm 5.11$ & $18.22 \pm 2.03^{\mathrm{c}}$ & $40.38 \pm 2.67^{\mathrm{c}}$ & $1.01 \pm 0.01^{\mathrm{ab}}$ & $174.72 \pm 3.14$ \\
Time: & & & & \\
Initial Time 1.T & $83.99 \pm 3.96^{\mathrm{b}}$ & $23.38 \pm 0.98^{\mathrm{a}}$ & $47.61 \pm 1.58^{\mathrm{a}}$ & $0.997 \pm 0.015^{\mathrm{b}}$ & $164.05 \pm 3.25^{\mathrm{b}}$ \\
Finally Time F.T & $98.92 \pm 4.97^{\mathrm{a}}$ & $17.23 \pm 1.01^{\mathrm{b}}$ & $39.33 \pm 1.33^{\mathrm{b}}$ & $1.08 \pm 0.026^{\mathrm{a}}$ & $175.79 \pm 3.56^{\mathrm{a}}$ \\
\hline Interaction between Treatment and Time: & & & \\
(G1) X 1.T & $73.8 \pm 6.79$ & $27.55 \pm 2.22$ & $53.58 \pm 2.81$ & $0.95 \pm 0.01$ & $151.16 \pm 1.82$ \\
(G2) X I.T & $86.8 \pm 11.24$ & $22.58 \pm 0.84$ & $48.35 \pm 0.79$ & $1.06 \pm 0.03$ & $168.17 \pm 7.5$ \\
(G3) X 1.T & $86.8 \pm 6.98$ & $20.18 \pm 1.24$ & $43.6 \pm 1.61$ & $0.99 \pm 0.015$ & $164.26 \pm 6$ \\
(G4) X 1.T & $88.6 \pm 7.22$ & $23.20 \pm 1.55$ & $44.9 \pm 4.32$ & $0.991 \pm 0.014$ & $172.62 \pm 2.8$ \\
(G1) X F.T & $106.2 \pm 0.92$ & $22.80 \pm 1.19$ & $46.28 \pm 1.89$ & $1.04 \pm 0.018$ & $180.87 \pm 11.31$ \\
(G2) X F.T & $79.7 \pm 15.33$ & $18.00 \pm 0.96$ & $40.42 \pm 1.51$ & $1.07 \pm 0.03$ & $178.84 \pm 5.38$ \\
(G3) X F.T & $107.3 \pm 4.82$ & $14.98 \pm 0.56$ & $34.78 \pm 1.09$ & $1.18 \pm 3.077$ & $166.65 \pm 5.38$ \\
(G4) X F.T & $102.4 \pm 5.57$ & $13.24 \pm 0.46$ & $35.87 \pm 1.00$ & $1.02 \pm 0.024$ & $176.81 \pm 6.1$ \\
\hline
\end{tabular}

$a, b$, and $c$ : Means denoted within the same column with different superscripts are significantly different at $P<0.01$ 